\title{
KAPLICA MATKI BOŻEJ UZDROWIENIA CHORYCH W GAJU NA WILEŃSZCZYŹNIE
}

W drodze z Wilna w kierunku Druskiennik, w odległości ok. 30 kilometrów od stolicy Litwy, prowadzi droga leśna do maleńkiej miejscowości Gaj, na Wileńszczyźnie, w rejonie (powiecie) trockim, zamieszkałej zaledwie przez 25 mieszkańców. W tej miejscowości stoi kaplica Matki Bożej Uzdrowienia Chorych, wybudowana w latach trzydziestych ubiegłego stulecia. W ołtarzu kaplicy jest kopia obrazu Matki Bożej z kościoła pw. Świętego Krzyżaa Ojców Boni-

* Ks. Waldemar W. Żurek - dr hab. historii Kościoła, prof. KUL, dyrektor Ośrodka Archiwów Bibliotek i Muzeów Kościelnych KUL, e-mail: zurek@kul.pl

${ }^{1}$ Biskup łucki (i późniejszy wileński) Paweł Algimunt Holszański (1536-1555), na miejscu cudownym (bijące źródło) gdzie zostali pochowani zamordowani franciszkanie - w ogrodzie Gosztołda (na terenie dzisiejszego Wilna) wzniósł w 1543 roku kaplicę. Wileński biskup Abraham Wojna (1631-1649) wybudował w 1635 roku przy kaplicy szpital, a do opieki nad chorymi sprowadził w tym roku do Wilna Braci Bonifratrów. Zakonnicy rozebrali kaplicę i wznieśli na jej miejscu kościół Świętego Krzyża. Pożar świątyni w 1737 roku spowodował konieczność jej odbudowy w 1748 roku. Wzniesiono wówczas fasadę z dwiema wieżami i frontonem, a przed fasadą zbudowano kruchtę nakrytą pulpitowym dachem. W czasie generalnego remontu kościoła przeprowadzonego w 1905 roku wykonano rokokową dekorację sklepień, postawiono nowy ołtarz główny, obok istniejących XVIII-wiecznych ołtarzy bocznych, a na zewnętrznym murze kościoła Św. Krzyża, nad wejściem, umieszczono obraz Matki Boskiej, który był „, [...] w wielkim poszanowaniu u ludu, który go, podobnie jak Ostrą Bramę, z odkrytą głową mijał [...]”. Z wybuchem drugiej wojny światowej bonifratrzy opuścili Wilno. W 1947 roku kościół zajęły siostry Niepokalanego Poczęcia Najświętszej Maryi Panny. Po 1949 roku władze zamknęły kościół i były klasztor. Budynek klasztoru przebudowano na mieszkania, a w 1976 roku kościół przekazano filharmonii wileńskiej i urządzono w nim salę koncertową. W 1990 roku świątynię zwrócono katolikom i sprowadziły się tu ponownie siostry Niepokalanego Poczęcia NMP. W kościele (obecnie przy placu S. Daukanto 1) bije nadal, uważane za cudowne, źródełko. J. Graniewicz, Wileńskie świątynie od czasów najdawniejszych do obecnych. Przewodnik historyczny, Kędzierzyn-Koźle/Wilno/Ryga 1993, s. 106; J. Kurczewski, Biskupstwo wileńskie, Wilno 1912, s. 358-359; G. Rąkowski. Ilustrowany przewodnik po zabytkach kultury na Litwie, Warszawa 1999, s. 355-356. 
fratró ${ }^{2} \mathrm{w}$ Wilnie, w przeszłości przy ich klasztorze. Kaplica posiada niecodzienny relikwiarz z czasów pierwszej wojny światowej. Lapidarną, ale wystarczającą historię relikwiarza znajdujemy spisaną na dwustronicowej kronice na kartkach pergaminowych. Znajduje się ona w miejscowym archiwum kaplicy w Gaju. Pozostałością z czasów pierwszej wojny światowej jest również płaskie pudełko, w którym w czasie wojny żołnierze nosili swoje dokumenty. Do dziś doroczny odpust obchodzony jest w kaplicy w Gaju w ostatnią niedzielę sierpnia na Matkę Bożą Uzdrowienie Chorych.

\section{Inicjator budowy kaplicy}

Inicjatorem budowy kaplicy w Gaju był brat Włodzimierz Andrzejewski, który wybrał drogę życia zakonnego w Zakonie Braci Bonifratrów. Urodził się dnia 15 czerwca 1881 roku w Żukach, w parafii Stare Troki, diecezji wileńskiej. Po wstąpieniu do bonifratrów jego życie zakonne rozpoczęło się od przyjęcia habitu tercjarskiego dnia 25 marca 1924 roku. Nie był członkiem zakonu jako brat. Nie złożył zakonnych ślubów prostych, ale był oblatem³. W zakonie nazywany

\footnotetext{
${ }^{2}$ Bracia Miłosierdzia, bonifratrzy - katolicki zakon szpitalny, któremu początek dała wspólnota świecka zorganizowana w 1540 roku w Grenadzie (Hiszpania) przez Jana Ciudad (późniejszy Jan Boży) w założonym przez siebie szpitalu. Zgromadzenie zakonne erygował w 1571 roku papież Pius V, nadając mu regułę św. Augustyna. W 1586 roku papież Sykstus V podniósł zgromadzenie do rangi zakonu, którego członkowie oprócz 3 ślubów podstawowych zobowiązują się specjalnym ślubem dożywotnio usługiwać chorym. W Polsce pierwszy klasztor bonifratrów powstał w 1609 roku w Krakowie, a w następnym roku powstał szpital, w 1812 roku przeniesiony na Kazimierz (obecnie dzielnica Krakowa). W latach 1630-1660 powstało najwięcej placówek tego zakonu w Polsce, w tym w 1635 roku w Wilnie. W 1633 roku erygowano prowincję polsko-litewską pw. Zwiastowania NMP. Do tego roku placówkami polskimi zarządzał wikariusz generalny. Szczególnie ważna i owocna była działalność bonifratrów na północno-wschodnich ziemiach Polski. W 1772 roku ich prowincja liczyła 14 placówek szpitalnych z 125 zakonnikami, a w klasztorze wileńskim żyło 14 bonifratrów. Do kasaty zakonu w 1843 roku bonifratrzy prowadzili w Wilnie szpital. To oni odegrali istotną rolę w polskim szpitalnictwie, zwłaszcza w XVII i XVIII wieku, gdy stanowili jedyną rodzinę zakonną, fachowo przygotowaną do pracy wśród chorych, dysponującą własnymi obiektami szpitalnymi z wykwalifikowanym personelem pielęgniarskim, farmaceutycznym i medycznym. Kasata licznych klasztorów doprowadziła do likwidacji prowincji polsko-litewskiej. Utrzymały się jedynie konwenty w Krakowie, Zebrzydowicach i Cieszynie, które w 1865 roku włączono do prowincji austriacko-czeskiej. Po odzyskaniu przez Polskę niepodległości, w kwietniu 1922 roku restytuowano prowincję polską, do której należało 9 konwentów. W 1924 roku bonifratrzy powrócili do Wilna, a w tamtejszym klasztorze otworzyli przytułek dla starców i jadłodajnię dla ubogich. W czasie drugiej wojny światowej klasztor i kościół bonifratrów w Wilnie zasadniczo nie ucierpiał. W lutym 1945 roku rozpoczęła się masowa repatriacja Polaków z Wilna i Wileńszczyzny. Podlegali jej także zapisani na wyjazd bracia bonifratrzy. Pierwszy wyjechał w marcu tego roku brat Józefat Konarzewski. Po nim w maju wyjechali: brat Paweł Czellik i Maciej Bujara - przeor. Pozostał brat Aureliusz Milski, który w niedługim czasie opuścił klasztor i Wilno na zawsze. J. Duchniewski, Bonifratrzy, bracia miłosierdzia, Ordo Hospitalarius Santi Joannis de Deo, w: Encyklopedia katolicka (dalej: EK), t. 2 Lublin 1995, kol. 799-801.

${ }^{3}$ Oblaci (łac. oblatus - ofiarowany) - w tradycji monastycznej były to osoby ofiarowane Bogu i związane z klasztorem bez składania ślubów zakonnych. W średniowieczu pojawiło się nowe rozumienie oblatów, którzy oddawali siebie i swoje dobra przez akt oblacji klasztorowi. Mogli oni nosić
} 
był bratem. Włodzimierz pojawia się w spisie członków wspólnoty konwentu w Cieszynie w 1925 roku jako tercjarz z funkcją ekonoma, czyli zaangażowanego w sferę administracyjną konwentu. Najprawdopodobniej na codzień zajmował się zaopatrzeniem konwentu ${ }^{4}$. W latach 1928-1929 był kolektorem na rzecz cieszyńskiego szpitala bonifratrów5 . Otrzymawszy stosowne zezwolenie wojewody ślą-

habity, zobowiązywali się do posłuszeństwa, obserwancji i stałości miejsca w łagodniejszej formie niż konwersi. Obecnie pod pojęciem oblata rozumie się osobę dorosłą, pełnoletnią, świadomą swojego wyboru, która jest związana z klasztorem przez fakt zamieszkania w klasztorze oraz złożenia zobowiązania. Oblaci służą klasztorowi swoją pracą, majątkiem, a klasztor przyjmuje ich do uczestnictwa w łaskach duchowych i przywilejach zakonu z obowiązkiem szczególnej opieki duchowej. Stolica Apostolska uznała oblatów $(1888,1891)$ i obdarzyła ich odpustami, a w 1895 roku zrównała w prawach z członkami III zakonu. W czasie obrzędu oblacji przyjmowano kandydata - oblata do zakonu. Nie składał on ślubów zakonnych w sensie prawa zakonnego ale zobowiązywał się do życia zgodnego z regułą zakonną, które nie obowiązuje pod sankcją grzechu ciężkiego. J. M. Marszalska, Oblaci, EK, t. 14, Lublin 2010, kol. 183-184.

${ }^{4}$ Brata Włodzimierza Andrzejewskiego nie należy mylić z Aleksandrem Andrzejewskim, w zakonie bratem Włodzimierzem. Urodził się dnia 3 czerwca 1881 roku w Żukach, w parafii Stare Troki, w diecezji wileńskiej. Był synem Jerzego i Heleny. Dnia 30 października 1890 roku w parafii Nowe Troku przyjął sakrament bierzmowania. Na wiosnę 1909 roku Aleksander Andrzejewski odpowiadając na wewnętrzny głos powołania zakonnego pragnął go realizować w zakonie posługującym chorym - u braci bonifratrów. W tym celu wyjechał do Krakowa z zamiarem wstąpienia do tego zakonu. Nowicjat zakonny u bonifratrów prowincji austriacko-czeskiej odbywał w Pradze Czeskiej początkowo jako postulant. Pomagał w tym czasie pracując w szpitalu praskim bonifratrów. Habit zakonny przyjął dnia 9 marca 1910 roku w Pradze. Śluby zakonne proste nowicjusz Andrzejewski złożył dnia 14 stycznia 1912 roku w konwencie św. Jana Chrzciciela w Wiedniu-Leopoldstadt i przyjął imię zakonne Włodzimierz. Był kolektorem klasztoru w Krakowie, który należał do prowincji austriackiej. Nie jest wykluczone, że opuścił zakon lub zaginął w czasie pierwszej wojny światowej. Nie występuje w żadnym nekrologu bonifratrów, a więc nie zmarł jako zakonnik-bonifratra. Archiwum Prowincjalne Braci Bonifratrów w Wiedniu (dalej: APBBW), Noviziat Wien u. Prag, Betieb: Einfache Profess 1912, Brat Eustachy Andrzejewski do Przewielebnego Ojca Prowincjała Tymoteusza Deutschel, Kraków dnia 5 stycznia 1912 roku (Pismo informujące o rodzicach Eustachego i przyjęciu przez niego sakramentu bierzmowania); Administrator Apostolski Diecezji Wileńskiej ks. Kazimierz Michalski, Opinia o kandydacie do stanu zakonnego, z dnia 5 VI 1909 roku, Nr 2897; Prośba o dopuszczenie do złożenia ślubów zakonnych nowicjusza Eustachiusza Aleksandra Andrzejewskiego do ojca prowincjała z stycznia 1912 roku, Kraków; Testament brata Eustachiusza Andrzejewskiego z dnia 14 stycznia 1912 roku, Wien-Leopoldstadt; Protokół sesji definitorium (rady) prowincji z 5 stycznia 1912 roku ( $\mathrm{Nr}$ 49/12); Conventus Pragensis ad. S. S. Apostolos Simonen et Juda in Bohemia Archi-Dioecesis Pragensis, w: Schematismus Ordinis S. Joannis De Deo Almae Provniciae Austriaco-Bohemicae S. Michaelis Archangeli pro Anno Domini 1912, Viennae 1912, s. 27. Archiwum Generalne Braci Bonifratrów w Rzymie (dalej: AGBR), W dwu rejestrach zmarłych (Rejestr Zmarłych 1851-1950 i Rejestr Współbraci Zmarłych 19371996) brat Eustachy Andrzejewski nie występuje.

${ }^{5}$ Pierwsi bracia przybyli na Śląsk Cieszyński - do Wędryni z Moraw. Na mocy testamentu z 7 marca 1693 roku Marszałek Księstwa Cieszyńskiego hrabia Adam Borek przekazał swoje dobra bonifratrom wrocławskim na wzniesienie klasztoru i szpitala koło Cieszyna. Konwent pw. Wniebowzięcia Najświętszej Maryi Panny erygowano 30 listopada 1700 roku a świątynię klasztorną konsekrowano 29 lipca 1719 roku. W okresie Rzeczypospolitej i zaborów konwent należał do prowincji austriacko-czeskiej. Po odzyskaniu przez Polskę niepodległości i reaktywowaniu prowincji polskiej 
skiego (1.B.P. 23/1 z dnia 30 XII 1926 r.) w książeczce zaopatrzonej w zezwolenie na przeprowadzanie kwest pieniężnych ofiarodawcy wpisywali swoje nazwisko, imię i kwotę oraz potwierdzali to własnoręcznym podpisem. W swego rodzaju księdze kasowej znajdują się liczne pieczęcie tuszowe urzędów i przedsiębiorstw z terenów II Rzeczypospolitej, które przekazywały fundusze na działalność szpitala bonifratrów w Cieszynie.

Od czasu do czasu brat Włodzimierz odwiedzał rodzinne strony - Gaj gdzie u swego stryjecznego brata spędzał czas. Ubolewał, że nie miał możliwości odmawiania brewiarzowych godzin kanonicznych w godnym miejscu. Po naradzie, wspólnie z Kazimierzem Trusewiczem, podjęli inicjatywę budowy bodaj małej kapliczki w Gaju. Jej budowę rozpoczęto w 1936 roku, a ukończono na wiosnę roku następnego. Dosłownie maleńka kapliczka, w stylu józefińskim, w której mieściło się do 5 osób. Ówczesny proboszcz parafii Połuknie (vel Połuknia) ${ }^{6}$, w dekanacie trockim - ks. Kazimierz Packiewicz ${ }^{7}$, rozpoczął starania u arcybiskupa wileńskiego Romualda Jałbrzykowskiego ${ }^{8}$ o uznanie kaplicy w Gaju jako

konwent przejęli bracia polscy. W czasie drugiej wojny światowej Niemcy przejęli klasztor. W lipcu 1946 roku bonifratrzy uruchomili część szpitala, aptekę i kościół. W 1950 roku apteka i gospodarstwo zostały upaństwowione, a szpital przekształcono w Dom Pomocy Społecznej. W latach 90. XX wieku przyniosły cieszyńskiemu konwentowi możliwość samodzielnego prowadzenia Domu Pomocy Społecznej dla Dorosłych i apteki oraz odzyskanie upaństwowionych dóbr zakonnych. Inwentarz archiwum klasztoru bonifratrów w Cieszynie, opr. M. Kuśka, J. Marecki, Cieszyn 2012, s. 6-7; Konwent p.w. Wniebowzięcia Najświętszej Maryi Panny, w: Bonifratrzy. Z Andaluzji do Polski, red. P. Foszczyńska, J. Sosnowska, Kraków 2009, s. 104-105.

${ }^{6}$ Kościół parafialny pw. św. Jana Chrzciciele w Połuknie ufundowany został w 1829 roku przez Jana Wolfganga. Od 1906 roku był przez parafian rozbudowany, a w 1926 roku dobudowano do świątyni wieże. Do parafii należały wioski, kolonie i osady: Angleniki, Baraki, Bakiciszki, Baliny, Dojnie, Gaj, Winklaryszki (v. Inklaryszki), Jałowiec, Jurgielany, Lidziańce, Łukańce, Merka, Madziuny, Nowosady, Połuknie, Podjeziory, Podropieje, Podłukańce, Ropieje-leśniczówka, Ropieje-koszar., Ropieje-kolonia, Szanderyszki, Sołka, Zwierzyniec, Zwierzyniec-kolonia. Folwarki: Biedugnie, Dugny, Krzyżanowo, Kajetaniszki, Łastowice, Żyliszki. Dwory należące do parafii: Andreiszki, Angleniki, Jeneliszki, Ołonie (v. Ołona), Połuknie, Ropieje. Catalog ecclesiarum et cleri archidioecesis vilnensis pro Anno Domini 1936, s. 104; Synodus Archidioecesana Vilnensis, Vilno 1932, s. 104; s. 517.

${ }^{7}$ Packiewicz Kazimierz (1884-1941) - kapłan archidiecezji wileńskiej. Święcenia kapłańskie otrzymał w 1911 roku. Od 1915 roku był proboszcz parafii Połuknia. Wybuch wojny niemiecko-sowieckiej w 1941 roku spowodował pierwsze ofiary w szeregach kapłanów archidiecezji wileńskiej. Dnia 25 czerwca 1941 roku zginął w Połukni tamtejszy proboszcz ks. Kazimierz Packiewicz. Wkraczające wojska niemieckie brutalnie mściły się za strzał, jaki padł w ich stronę w tej miejscowości. Ponadto Niemcy zamordowali wówczas szereg osób, spalili kościół i plebanię. Catalog ecclesiarum et cleri archidioecesis vilnensis pro Anno Domini 1936, s. 104, 168; T. Krahel, W Generalnym Okręgu Litwa, „Czas Miłosierdzia”. Białostocki biuletyn kościelny, on line (dostęp: 5.09.2015)

${ }^{8}$ Jałbrzykowski Romuald (1876-1955) - metropolita, arcybiskup wileński. Święcenia kapłańskie otrzymał w 1901 roku. Był kapelanem biskupa Antoniego Baranowskiego, od 1902 roku profesorem, od 1909 roku wicerektorem seminarium duchownego w Sejnach. W czasie pierwszej wojny światowej organizował akcję charytatywną, także dla jeńców rosyjskich. W 1918 roku został biskupem pomocniczym sejneńskim, od 1921 roku rządził częścią diecezji augustowskiej w granicach Polski, jako delegat apostolski. W 1925 roku został ordynariuszem utworzonej diecezji 
publicznej, z możliwością odprawiania Mszy Świętych. Jej poświęcenie odbyło się 18 lipca 1937 roku. Najcenniejszym skarbem tamtejszej kaplicy jest cudowny obraz Matki Bożej Uzdrowienia Chorych. Obraz na płótnie, będący wierną kopią obrazu z kościoła Świętego Krzyża przy klasztorze ojców bonifratrów w Wilnie, namalował w 1936 roku Romuald Warachowski. A Matka Boża w tym wizerunku popularnie zwana jest przez wiernych Bonifraterską. W lipcu 1939 roku kaplica została powiększona.

$\mathrm{Na}$ potrzeby wiernych powstała specjalna modlitwa do Matki Bożej Uzdrowienie Chorych, przed jej cudownym obrazem w kościele bonifraterskim Świętego Krzyża w Wilnie, z której korzystali wierni w kaplicy w Gaju, prosząc Boga w przedstawianych intencjach za przyczyną Matki Bożej i wzywając jej wstawiennictwa.

O Dziewico Najczystsza, jedyna ucieczko grzeszników i prawdziwa Matko nasza, Uzdrowienie chorych, oto ja nędzny grzesznik, staję u stóp ołtarza Twego onieśmielony i upokorzony z powodu ciężkich grzechów moich, które mnie odwiodły od Boga i od Ciebie, droga Matko moja, Maryo. O Pośredniczko i Opiekunko moja, zwróć Swoje oczy litościwe na mnie, wejrzyj na mój żal i wyjednaj mi łaskę przebaczenia. Twoim jestem o Matko Boska - Uzdrowienie chorych, błagam Cię o litość i miłosierdzie, tyś je okazywała swoim czcicielom, nie opuszczaj mnie niegodnego i spraw, aby Krew przelana Syna Twego nie była dla mnie na zgube, lecz na zbawienie. Stałaś pod krzyżem, gdy Syn Twój wśród największych boleści umierał, spraw więc abym i ja przeciwności tego świata cierpliwie znosił i niósł swój krzyż, naśladując Cię we wszystkim. Jeżeli kiedy, to przede wszystkim dziś mi tej pomocy potrzeba, abym nie upadł i nie uległ zniechęceniu. Uciekają się do Ciebie wszystkie narody; wejrzyj na niedolę cierpiącej ludzkości, aby rychło powróciła do pokuty i do Boga, aby zakwitła ponownie gorąca wiara, na całym świecie, a spokój, zgoda i jedność niech się stanie udziałem wszystkich mieszkańców ziemi.

Tylekroć okazywałaś swoją opiekę nad nami, okaż ją i teraz, gdyż dziś tem większej pomocy od Ciebie wyglądamy.

O Matko, Uzdrowienie chorych, pociesz nas i daj nam łaskę wytrwania w dobrem, abyśmy mogli wraz z Tobą już na ziemi, a potem w niebie chwalić Boga wiecznie. Amen?.

\footnotetext{
łomżyńskiej, a w 1936 roku mianowany został arcybiskupem metropolitą wileńskim. Do 1939 roku zwizytował 4-krotnie wszystkie parafie. W 1927 roku koronował cudowny obraz Matki Bożej Miłosierdzia w Ostrej Bramie. W 1931 roku odbył (pierwszy od 1744) synod archidiecezjalny, a w 1939 roku prowincjalny. W czasie okupacji niemieckiej 1942-1944 był internowany w Mariampolu, przez władze radzieckie więziony w 1945 roku w Wilnie. Od 1945 roku zarządzał archidiecezją wileńską z Białegostoku, gdzie zorganizował kurię biskupią w części archidiecezji wileńskiej pozostającej w granicach Rzeczypospolitej Polskiej. S. Hołodok, Jałbrzykowski Romuald, w: EK, t. 7 Lublin 1997, kol. 737-738.

${ }^{9}$ Nihil, Vilno, d. 13 Septembris 1933 a., Leon Żebrowski, librum censor. Imprimatur, Vilno, d. 13 Septembris 1933 a. Nr 14560 L. 3, R. Jałbrzykowski, Archip.-Metrop., J. Poniatowski, Notarius Curiae.
} 
W zachowanej księdze próśb i podziękowań znajdują się wpisy łask otrzymanych przez modlących się wiernych, z czasów drugiej wojny światowej, za przyczyną Matki Boskiej Uzdrowienie Chorych ${ }^{10}$.

Pierwszy wpis ( $\mathrm{Nr}$ 1) jako podziękowanie Matce Bożej Uzdrowienia Chorrych pochodzi od niepiśmiennej osoby z miejscowości Wisztelany należącej do parafii Zwiastowania Najświętszej Maryi Panny w Starych Trok (brak daty):

Z głęboką czcią i pokorą składam podziękowanie N.M.P. Uzdrowienie chorych w Gaju, która wysłuchała moje modlitwy i przywróciła mi zdrowie.

Byłam bardzo poważnie chora na łożach moich boleści. Leżałam przez kilka miesięcy pomimo troskliwej opieki domowej. Rodzeństwo było zupełnie bezradne. $Z$ pełną ufnością udałam się do N. M. P. Gajowskiej.

Z pokorą postanowiłam pieszo udać się do Gaju, do obrazu Uzdrowienia Chorych. Byłam bardzo osłabiona. Syn mój wiedząc, że jestem słaba chciał zaprzęgnąc konia i mnie zawieść. Natomiast córki mnie nie puszczały z domu, bojąc się abym w drodze nie umarła.

Ja pomimo przestróg i odradzeń postanowiłam, że pieszo pójdę do tej Pani, w której są ręku wszystkie skarby. Pomalutku szczęśliwie zaszłam do Gaju. Tu jak córka przed swoją najmilszą Matką wynużyłam swoje boleści i cierpienia. Wnet uczułam ulgę i powróciłam do domu nie spoczywając.

Z każdym dniem siły mi wzrastały. Dziś czuję się zupełnie zdrowa, za co niech będzie po wieczne czasy Bogu chwała a cześć N. M. Pannie. +++ (podpis za niepiśmienną)".

Kolejny zapis (nr 2) cierpiącej na dolegliwości mieszkanki Wilna z dnia 14 I 1942 roku:

Podziękowanie M. B. Gajowskiej.

Prawie od małych lat cierpiałam na romatyzm. [sic] Nie mogłam nocami sypiać, bo miałam silne bóle. Zatem poleciłam się M. B. Gajowskiej, co spowodowało mi ulgę i zdrowie. A więc niech będą dzięki i chwała M. B. Gajowskiej aż po wieczne czasy! Jan S.

\section{Wyjątkowy relikwiarz w kaplicy w Gaju}

Znajdujący się w kaplicy gajowskiej relikwiarz, był niegdyś własnością brata Włodzimierza - bonifratry. Już w czasie pierwszej wojny światowej gromadził on łuski po kulach austriackich, pruskich i rosyjskich. Potem powziął zrealizować osobliwy plan wykonania relikwiarza z łusek po nabojach, w postaci monstrancji do kaplicy w Gaju. Wygląd zewnętrzny kul sam dokładnie opisał:

Kule podłużne tępe to są austriackie, kule spiczaste krótkie to są pruskie a podobne do tych kul, kule przy samym pierścieniu przy szkiełku to są rosyjskie.

${ }^{10}$ Archiwum Kaplicy w Gaju, Księga Wpisów otrzymanych łask od cudownego Obrazu N. M. Panny Uzdrowienia Chorych w Gaju, s. 1-3. 
Plan i projekt relikwiarza sporządził brat Włodzimierz. Prace ślusarskie wykonał pan Edward Kowalski, a wykończył znakomity krakowski mistrz-artysta Henryk Waldyn ${ }^{11}$ w swojej Pracowni Cyzelrsko-Bronzowniczej przy ul. Felicjanek w Krakowie ${ }^{12}$, twórca takich dzieł sztuki brązowniczej, jak buława marszałka Rydza Śmigłego oraz kopii Globusa Jagiellońskiego, eksponowanych w Muzeum Uniwersytetu Jagiellońskiego. Do wykonania relikwiarza użyto 51 łusek po kulach austriackich, 21 lusek po kulach pruskich oraz 16 lusek kul rosyjskich. Łuski rosyjskie tworzą wokół szkiełka w relikwiarzu pierścień. Dookoła pierścienia upleciona jest złocona korona cierniowa. Łuski pruskie i austriackie, przeplatane między sobą, tworzą w całości rodzaj pierścieni. Na szczycie relikwiarza umieszczono krzyżyk z łusek ozdobiony promieniami z wizerunkiem Zbawiciela. Poświęcenia relikwiarza wysokiego na 36 centymetrów dokonał dnia 26 grudnia 1914 roku kapelan wojskowy o. Modestus Klaczko z zakonu św. Benedykta. W relikwiarzu znajdują się relikwie założyciela Ojców Bonifratrów - św. Jana Bożego ${ }^{13}$, które zostały w nim umieszczone w 1930 roku przez o. Rafała Mojeca,

${ }^{11}$ Prace Henryka Waldyna znajdują się w Muzeum Katedralnym na Wawelu. Po modernizacji muzeum, dnia 5 czerwca 1995 roku kard. Franciszek Macharski dokonał otwarcia nowej ekspozycji Muzeum Katedralnego, gdzie w pierwszej sali na parterze umieszczono przedmioty o charakterze królewskim, m.in. kopie insygniów grobowych króla Zygmunta Augusta, Anny Jagiellonki, Stefana Batorego i Władysława IV, wykonane w okresie międzywojennym przez krakowskiego złotnika Henryka Waldyna. J. Urban, Muzeum Katedralne na Wawelu, „Muzealnictwo” 49 (2008) s. $124-$ 125.

${ }^{12}$ Reklama firmy artysty Henryka Waldyna (rytownik i cyzeler): Pracownia Cyzelsko-Bronzownicza wykonuje: kielichy, monstrancje, figury, płaskorzeźby, antyki złocone ogniowe i patynowe, odnawia zastawy srebrne. Kraków, ul. Felicjanek 5 - Boczna L. 7. „Rzeczy Piękne” organ Muzeum Przemysłowego w Krakowie 6 (1927) nr 7-8, s. 3.

13 Jan Ciudad (1595-1550) - Jan Boży, Portugalczyk, święty, założyciel Zakonu Braci Bonifratrów. Urodził się w miasteczku Montemoro-Novo, w diecezji Evora. W wieku 8 lat uciekł z domu, przyłączając się do wędrownego mnicha, któremu rodzice użyczyli noclegu. Następne 20 lat spędził u rządcy majątku hrabiego Oropesy w Hiszpanii, który przygarnął Jana i wychował jak własne dziecko, planując mu oddać swą córkę za żonę. Jako ochotnik zaciągnął się do wojska w 1523 roku. Wraz z wojskiem Karola V walczył z Franciszkiem I, królem Francji, o Fuenterrabię. W 1532 roku wykazał się odwagą i męstwem podczas węgierskiej odsieczy Karola V w obronie Wiednia przeciwko tureckiemu sułtanowi Sulejmanowi II. Powróciwszy po 30 latach do domu rodzinnego przeżył wstrząs i załamanie psychiczne, dowiedziawszy się że matka wkrótce po jego ucieczce z domu zmarła z rozpaczy, a ojciec trapiony zgryzotą dokończył życia we franciszkańskim klasztorze. Ogarnięty wyrzutami sumienia ponownie uciekł z ojczystej ziemi, tym razem do Afryki, gdzie w Cuecie, warownym mieście zdobytym na Maurach przez Portugalczyków, zaznał niewolniczej pracy i przeżył osobisty wstrząs, gdy jego przyjaciel porzucił katolicyzm i przeszedł na islam. Mając 43 lata powrócił do Hiszpanii i w Grenadzie założył sklepik z książkami. Pod wpływem kazania św. Jana z Avili o św. Sebastianie,w 1539 roku przeżył duchowe nawrócenie. Jan z Avili stał się jego kierownikiem duchowym i nakłonił go do poświęcenia się służbie ubogim i chorym. Własną pracą zdobył fundusze i wraz z pomocnikami w 1540 roku założył szpital-przytułek dla potrzebujących, w którym cierpiący otrzymywali nie tylko pomoc medyczną, ale i opiekę duchową, traktowani ze współczuciem i miłosierdziem. To dzieło uważa się za zalążek zakonu. Podziwiany za życia i nazywany „Bożym”, otoczony czcią religijną po śmierci, kanonizowany został w 1690 roku. Papież Leon XIII ogłosił św. Jana wraz z św. Kamilem Lellisem patronem chorych i szpitali, 
generała zakonu ${ }^{14}$. W 1937 roku relikwiarz został podarowany przez o. Włodzimierza do kaplicy rodzinnej Matki Bożej Uzdrowienia Chorych w Gaju.

Brat Włodzimierz nie cieszył się długo z oddania kaplicy do użytku wiernych. W czasie drugiej wojny światowej był zakrystianinem w kościele bonifraterskim w Wilnie. W lipcu 1944 roku, podczas wycofywania się Niemców z Wilna, zasadniczo kościół i klasztor nie odniósł większych szkód. Natomiast konwent poniósł wielką stratę w osobie brata Włodzimierza Andrzejewskiego, ówczesnego zakrystianina. Idąc do ks. prałata Franciszka Wołodźki, tuż przed jego domem, przy ulicy Wileńskiej 46 został trafiany kulą dnia 11 lipca 1944 roku. Do klasztoru przyniesiono go już martwego. Jego zwłoki zostały tymczasowo pochowane przy furcie klasztornej. Po zakończeniu działań wojennych na terenie Wilna, zwłoki brata Włodzimierza zostały wyjęte $\mathrm{z}$ tymczasowego grobu, przewiezione na cmentarz na Rossie i pochowane w zakonnym grobowcu. Obowiązki zakrystianina przejął po bracie Włodzimierzu brat Aureliusz Milski, pełniący obowiązki administratora kościoła i klasztoru ojców bonifratrów w Wilnie ${ }^{15}$.

Obecni rdzenni mieszkańcy Gaju to Polacy, których przodkowie mieszkali w tej miejscowości od pokoleń. Maleńka wieś ma długą i interesującą historię ${ }^{16}$. W przeszłości, w niedalekiej odległości - w Ołonie Opaciskiej stał dwór, którego właścicielem był generał rosyjski Reklicki. Do Ołony należały okoliczne ziemie. Natomiast w odległości trzech kilometrów od tej miejscowości, w osobnych granicach rozciągało się 6 włók ${ }^{17}$ lasu należącego do dworu, z wybudowaną gajówką dla gajowego. Właściciel majątku Ołony postanowił sprzedać las. Drzewo kupili Żydzi a ziemię katolicy. Na czele kupców do nabycia gruntów stanęli bracia Jerzy i Adam Andrzejewscy a gospodarze (Sawiccy, Sładkiewiczowie, Zieniewiczowie) zdecydowali wybudować w pobliżu gajówki swoje domostwa. Tak powstało niewielkie osiedle, które od leśnej gajówki przyjęło nazwę Gaj ${ }^{18}$.

a papież Pius XI pod ich opiekę oddał w 1930 roku pielęgniarki i pielęgniarzy. K. Cichoń, A. Kuczyńska, Jan Boży, Jan Ciudad, w: EK, t. 7 Lublin 1997, kol. 763; A. Orman, Pozostaje jedynie dobre dzieło, w: Bonifatrzy, s. 10-11.

${ }^{14}$ Takie nazwisko jest zanotowane na kartce pergaminowej w zeszycie przechowywanym od lat w kaplicy. Otóż generałem zakonu Braci Bonifratrów był wówczas ojciec Faustyn Calvo, wybrany dnia 24 kwietnia 1928 roku i te funkcję sprawował przez 6 lat.

${ }^{15}$ Br. Aureliusz Milski, Sprawozdanie brata Aureliusza Milskiego pełniącego w latach 19421946 obowiązki administratora kościoła i klasztoru ojców bonifratrów w Wilnie za rok 1939-1946, Wilno 1946 (Plac Napoleona «Kutozowa» nr 6), s. 5, mps - Archiwum Konwentu Bonifratrów w Krakowie.

${ }^{16}$ Historia miejscowości opisana jest w języku polskim, w odnalezionym ponad 200-stronicowym zeszycie-kronice, pt. Kronika Kaplicy Matki Boskiej Uzdrowienia Chorych w Gaju. L24.1t/pl/ społeczeństwo/ltem/106772-poluknia-joja-swój-kaalendarz (dotęp: 01.10.2016).

${ }^{17}$ Włóka - dawna (średniowieczna) miara powierzchni odpowiadająca wielkością łanowi chełmińskiemu, czyli 30 morgów - 17,955 ha - 179,550 metrów kwadratowych. Nazwa ta bywała często synonimem łanu, była w szerokim użyciu na Mazowszu i na wschodnich terenach Rzeczypospolitej.

${ }^{18}$ A. Sobolewska, Jubileusz 75-lecia wyświecenia kaplicy w Gaju, „Kurier Wileński”. Dziennik Polski na Litwie z 25-27 sierpnia 2012 r. Nr 163 (16957), s. 4. 
Od początku kaplicą opiekują się tamtejsi mieszkańcy, których przodkowie ją zbudowali. Jednymi z nich są Anna i Romuald Trusewiczowie, którzy już ponad dwadzieścia lata troszczą się o kaplicę, stanowiącą serce tej miejscowości ${ }^{19}$.

Obecnie w kaplicy liturgia mszalna sprawowana jest we środy i w niedziele. W środy o godz. 18.00 wierni szczególnie modlą się o uzdrowienie chorych, a w niedzielę o godz. 10.00 sprawowana jest Eucharystia z homilią. Posługę pastoralną pełni w niej proboszcz dwóch parafii: Połuknie (od 2004 roku) i Rudziszeki - ks. Tadeusz Śvedewičius. Oprócz miejscowych wiernych, na niedzielną Mszę Świętą przybywają także mieszkańcy okolicznych miejscowości ${ }^{20}$.

\section{Jubileusz poświęcenia kaplicy w Gaju}

W tej niewielkiej miejscowości w 2012 roku uroczyście świętowano 75-lecie poświęcenia kaplicy Matki Bożej Uzdrowienia Chorych. W organizację obchodów zaangażowała się młodzież kół Związku Polaków na Litwie z Połukni i Międzyrzecza. Dzięki wsparciu finansowemu Samorządu Rejonu Trockiego odrestaurowano relikwiarz oraz dokonano gruntownego odnowienia kaplicy na zewnątrz ${ }^{21}$.

Kilkudniowe uroczystości jubileuszowe zaplanowano w dniach 26-29 sierpnia 2012 roku. Rozpoczęto je w niedzielę Mszą Świętą w kaplicy o godzinie 14.00. Sprawowali ją księża parafii w Połukni i Rudziszkach, którzy w przeszłości pełnili w kaplicy w Gaju posługę duszpasterską oraz zaproszeni kapłani. W ciągu kolejnych trzech dni 27-29 sierpnia celebrowano Mszę Świętą o godz. 18.00. Na zakończenie uroczystości jubileuszowych w Gaju, w środę 29 sierpnia odbył się koncert zespołu Pieśni i Tańca „Połuknianie”. Zaprezentował się także polski wykonawca Iwan Komarenko ${ }^{22}$ oraz artyści wileńscy: Wincuka, Katarzyna Niemyčko, Agnieszka Dobrowolska, Luba Nazarenko. Organizatorzy nie kryli radości z frekwencji słuchaczy, zarówno na liturgii, jak i na koncercie, zważywszy że

${ }^{19}$ Tak relacjonuje Renata Joknieně, nauczycielka muzyki i organizator imprez kulturalnych ze starostwa w Połukni.

${ }^{20}$ Ksiądz proboszcz komentuje: „Gaj to niezwykłe miejsce, w którym do kościoła chodzi sto dwadzieścia procent mieszkańców. Oprócz tych dwudziestu pięciu mieszkańców Gaju na niedzielną Mszę św. przybywają zwykle mieszkańcy okolicznych miejscowości”. Artykuł: Cudowny koncert w Gaju, http://www.wilnoteka.lt.pl (dostęp: 18.01.2013).

${ }^{21}$ Sobolewska, Jubileusz 75-lecia wyświecenia kaplicy w Gaju, s. 1, 4.

${ }^{22}$ Iwan Komarenko, ros. Иван Комаренко - urodził się dnia 12 kwietnia 1976 roku w niżnieilimskim rejonie obwodu irkuckiego, wokalista, członek zespołu „Ivan i Delfin”. Jako czternastolatek zaczął występować publicznie. Rok później rozpoczął naukę w średniej Szkole Muzycznej w Bracku. W wieku siedemnastu lat przeniósł się do Irkucka na wydział piosenki estradowej. Po uczestnictwie w pielgrzymce Jana Pawła II w Polsce, postanowił zostać w naszym kraju. Zamieszkał w podwarszawskich Laskach, opiekując się niewidomymi w zakładzie dla niewidomych, pracując w zamian za jedzenie i ubranie. Po powrocie do Rosji, rozpoczął w Irkucku naukę w szkole wieczorowe. Następnie w Polsce przez rok uczęszczał do szkoły języka polskiego dla cudzoziemców we Wrocławiu. Po jej ukończeniu podjął studia na Uniwersytecie Warszawskim na Wydziale Polonistyki. Równolegle rozpoczął naukę w trzyletnim studium muzycznym na Wydziale Piosenki Estradowej. W 2010 r. Iwan Komarenko otrzymał polskie obywatelstwo. http://pl.wikipedia.org/ wiki/Iwan_Komarenko (dostęp: 30.01.2013). 
był to dzień powszedni. Przybyło setki osób z Wileńszczyzny i nie tylko. Muzyczny występ zorganizowali: parafia św. Jana Chrzciciela w Połukni, połukniańska filia Domu Kultury Rejonu Trockiego oraz mieszkańcy Gaju.

Koncert był udany, a jego wykonawcy znani są na Litwie. Ich występ dał wiele przeżyć dla słuchaczy, a wykonawcy emanowali z siebie niebywałą energią. Wszyscy, zarówno młodzi jak i starsi byli zadowoleni, gdyż było tradycyjnie i nowocześnie. Dla wielu, którzy przybywają do Gaju najważniejsza jest Matka Boża. Potrzebujący przyjeżdżają nieustannie do Niej, by dziękować za opiekę i zdrowie, prosić Ją o uzdrowienie a nawet o cud. To potwierdza wspomniana pani Renata, współorganizatorka koncertu, która jak najbardziej wierzy w cuda ${ }^{23}$.

Tamtejsi mieszkańcy przygotowują się do kolejnego świętowania w 2017 roku - 80. rocznicy kaplicy w Gaju i obecności oraz wstawiennictwa u Boga Matki Bożej Uzdrowienia Chorych. Oby i ten jubileusz przyniósł oczekiwane „owoce” dla proszących i czcicieli Matki Bożej w jej wizerunku Uzdrowienia Chorych.

Słowa kluczowe: historia Wileńszczyzny, archidiecezja wileńska, osobliwości na Wileńszczyźnie

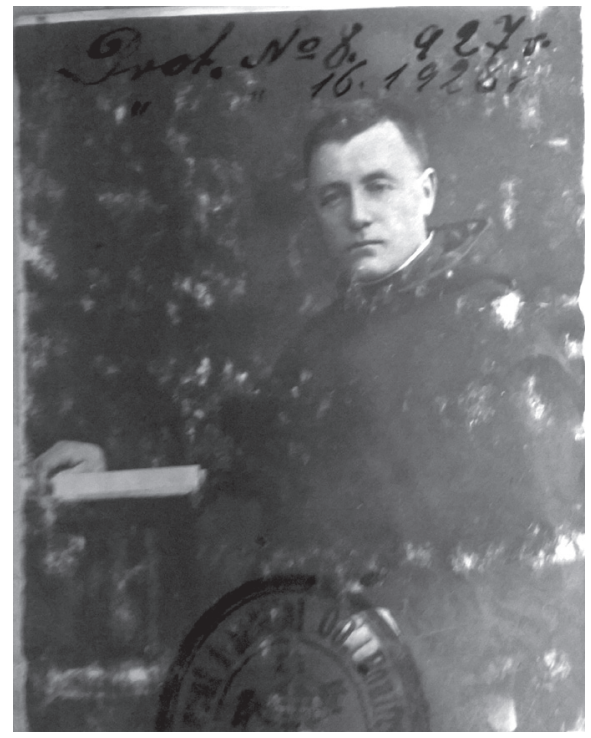

Fot. 1. Br. Włodzimierz Andrzejewski, oblat. Zbiory Archiwum Bonifratrów w Cieszynie.

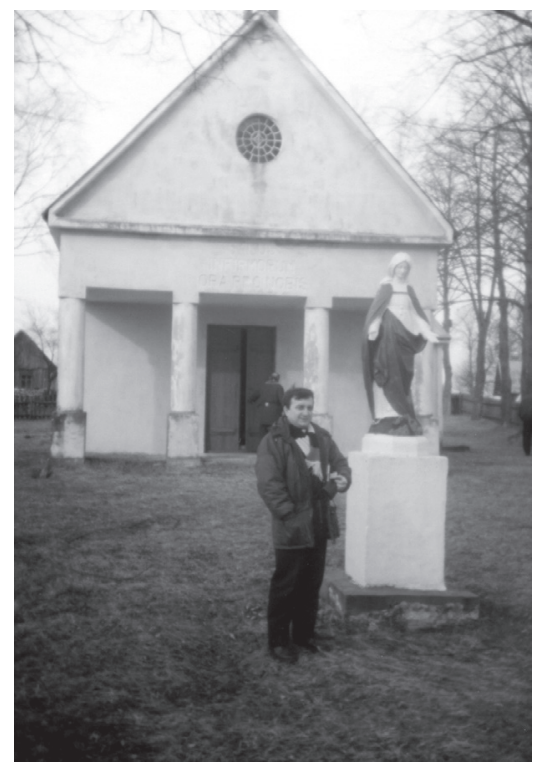

Fot. 2. Kaplica w Gaju, 1998 r. Zbiory ks. Waldemara W. Żurka SDB.

${ }^{23}$ To potwierdza wspomniana Renata Joknieně. Dnia 9 lipca 1939 roku komisyjnie stwierdzono cudowne uzdrowienie Konstancji Trombaczyk, co zostało zapisane w zeszycie, który od kilkudziesięciu lat leży w kaplicy. Cudowny koncert w Gaju, http://www.wilnoteka.lt.pl (dostęp: 18.01.2016). 


\section{BIBLIOGRAFIA}

\section{Archiwalia}

Archiwum Generalne Braci Bonifratrów w Rzymie - AGBR

Rejestr Współbraci Zmarłych 1937-199 AGBR

Rejestr Zmarłych 1851-1950

Archiwum Prowincjalne Braci Bonifratrów w Wiedniu - APBBW

Noviziat Wien u. Prag, Betieb: Einfache Profess 1912.

Archiwum Kaplicy w Gaju - APG

Księga Wpisów otrzymanych łask od cudownego Obrazu N. M. Panny Uzdrowienia Chorych w Gaju (rkp).

Archiwum Konwentu Bonifratrów w Krakowie - AKBK

Milski Aureliusz, Sprawozdanie brata Aureliusza Milskiego pełniącego w latach 19421946 obowiązki administratora kościoła i klasztoru ojców bonifratrów w Wilnie za rok 1939-1946, Wilno 1946 (mps).

\section{Opracowania}

Catalog ecclesiarum et cleri archidioecesis vilnensis pro Anno Domini 1936, Vilnae 1936.

Schematismus Ordinis S. Joannis de Deo Almae Provinciae Austriaco-Bohemicae S. Michaelis Archangeli pro Anno Domini 1912, Vienne 1912.

Cichoń Krzysztof, Kuczyńska Agnieszka, Jan Boży, Jan Ciudad, EK, t. 7 Lublin 1997, kol. 763.

Duchniewski Jerzy, Bonifratrzy, bracia miłosierdzia, Ordo Hospitalarius Santi Joannis de Deo, EK, t. 2 Lublin 1995, kol. 799-801.

Graniewicz Janusz, Wileńskie świątynie od czasów najdawniejszych do obecnych. Przewodnik historyczny, Kędzierzyn-Koźle/Wilno/Ryga 1993.

Hołodok Stanisław, Jałbrzykowski Romuald, EK, t. 7 Lublin 1997, kol. 737-738.

Konwent p.w. Wniebowzięcia Najświętszej Maryi Pannyj, w: Bonifratrzy. Z Andaluzji do Polski, red. Paulina Foszczyńska, Jolanta Sosnowska, Kraków 2009, s. 104-105.

Kurczewski J., Biskupstwo wileńskie, Wilno 1912.

Orman Aleksnadra, Pozostaje jedynie dobre dzieło, w: Bonifratrzy. Z Andaluzji do Polski, red. L. Sosnowski, Kraków 2009, s. 10-13.

Rąkowski Grzegorz, Ilustrowany przewodnik po zabytkach kultury na Litwie, Warszawa 1999.

Sobolewska Alina Jubileusz 75-lecia wyświecenia kaplicy w Gaju, „Kurier Wileński”. Dziennik Polski na Litwie z 25-27 sierpnia 2012 r. Nr 163 (16957), s. 1, 4.

Urban Jacek, Muzeum Katedralne na Wawelu, „Muzealnictwo”, 49 (2008) s. 124-125.

Synodus Archidioecesana Vilnensis, Vilno 1932.

Żywot jak słońce. Wspomnienia księdza prałata Józefa Obrębskiego, opr. Jan Sienkiewicz, Wilno 1996.

\section{Internet}

Cudowny koncert w Gaju, http://www.wilnoteka.lt.pl (dczyt z 18.01. 2013).

Iwan Komarenko, http://pl.wikipedia.org/wiki/Iwan_Komarenko (odczyt z 30.01. 2013).

Krahel T., W Generalnym Okręgu Litwa, "Czas Miłosierdzia”. Białostocki biuletyn kościelny, on line (dostęp z 05.09. 2015).

„Kronika Kaplicy Matki Boskiej Uzdrowienia Chorych w Gaju”, 24.lt/pl/społeczenstwo/ ltem/106772-poluknia-joja-swój-kalendarz (dostęp: 01.10.2016). 


\title{
THE CHAPEL OF OUR LADY HEALTH OF THE SICK IN GAJ IN THE VILNIUS REGION
}

\begin{abstract}
Summary
In the Vilnius region near Troki there is the tiny village of Gaj situated in the forest; it is part of the parish of Stare Troki in the Archdiocese of Vilnius. The village is inhabited by dozens of residents who are Polish. In this village there is a chapel of Our Lady Health of the Sick, which was built in the thirties of the last century thanks to the efforts of Włodzimierz Andrzejewski's brother (a member of the Brothers Hospitallers of Saint John of God) and his family. It was consecrated in 1937. The chapel houses a copy of the image of Our Lady Health of the Sick from the Holy Cross Church of the Brothers Hospitallers in Vilnius. To this day, on the last Sunday in August, the faithful gather in the parish fair to give thanks to God, through the intercession of Our Lady, for everything they received from Him.
\end{abstract}

Keywords: the history of the Vilnius region, the Archdiocese of Vilnius, the Polish places of interest in the Vilnius region 